\title{
The Exploratory Study of The Company's CSR Motives: The Case of Two Companies In Indonesia
}

\author{
Tengku Ezni BALQIAH, Fanny MARTDIANTY and Rifelly Dewi ASTUTI
}

Faculty of Economics and Business, Universitas Indonesia, Jakarta, Indonesia

Correspondence should be addressed to: Fanny MARTDIANTY; fanny.martdianty@ui.ac.id

Received date: 4 November 2019; Accepted date:27 January 2020; Published date: 23 June 2020

Academic Editor: Nizar Khaled Mohammad Dwaikat

Copyright (C) 2020. Tengku Ezni BALQIAH, Fanny MARTDIANTY and Rifelly Dewi ASTUTI. Distributed under Creative Commons Attribution 4.0 International CC-BY 4.0"

\begin{abstract}
Corporate Social Responsibility (CSR) has been a subject of research interest and has drawn awareness for researchers and business practitioners from various fields. When doing their CSR activities, companies might have several motives that could be beneficial not only for the company itself, but also for their stakeholders. This paper focuses on a specific CSR initiative (i.e. scholarship program) provided by two companies in Indonesia. Semi-structured interviews were conducted with the representatives of the companies to explore the company's motives. A cross-case analysis was also presented to describe the findings. The findings revealed that both firm-serving and public-serving motives were prevalent as the motives for doing CSR activities. The interviews also suggested that belief, value and religious thoughts would also be relevant factors for an organization to initiate its CSR activity.
\end{abstract}

Keywords: CSR, CSR motives, CSR initiatives, Scholarship, Indonesia

\section{Introduction}

Scholars and business practitioners have put much attention to the concept of Corporate Social Responsibility (CSR) and the role of business in societies (Benn \&
Bolton 2011 and Pearce \& Manz, 2011). Because of the financial crisis, corporate scandals and environmental threats, the society is more alerted whether corporations do their business responsibly and ethically or not. (Buchholtz and Carroll,

Cite this Article as: Tengku Ezni BALQIAH, Fanny MARTDIANTY and Rifelly Dewi ASTUTI (2020), "The Exploratory Study of The Company's CSR Motives: The Case of Two Companies in Indonesia”, Journal of Southeast Asian Research, Vol. 2020 (2020), Article ID 182970, DOI: 10.5171/2020.182970 
2008). CSR is a company's commitment to showing concern for the community (Kotler and Lee, 2005). These commitments include how the company responsibly manages the environmental, social and economic effects of its operations and how the initiatives are relevant to the public expectations. CSR activities have the potentials to create a strong relationship between the company and the stakeholders (e.g. customers and community) (Peloza and Shang, 2011). The ability of CSR to create corporate values is highly dependent on its ability to produce positive relationships with these stakeholders (Barnett, 2007). CSR is one of the activities that can not only increase profits but also have an impact on social and environmental issues (Peloza and Shang, 2011). Although many companies have implemented CSR activities, it must be recognized that these activities are directly or indirectly encouraged by stakeholders (Kiessling, Isaksson and Yasar, 2015).

There are many forms of CSR activities implemented by companies and these initiatives are based on various issues that the companies support. The most popular CSR activities are donations to communities, voluntary participation in community activities and energy efficiency or waste treatment (Torugsa, O'Donohue and Hecker, 2013).Various forms of CSR activities, aimed specifically at stakeholders, will produce benefits and different values for the parties associated with the CSR activities. Usually, when the CSR targets are for the community, companies initiate programs related to education, health, well-being, happiness and stability (Balqiah et al. 2011). A scholarship is a form of community engagement and CSR activities that focus on individuals. In general, scholarships are given to support the recipient's education process based on merit and other reasons. There are various forms of scholarships that are given to the recipients. Some companies may provide the recipients with only tuition fees or living expenses or a combination of these two. Others may also provide the recipients with some development programs (e.g. seminars, workshops or plant tours).
Companies use CSR to build and strengthen relationships with multiple stakeholders (e.g. consumers, suppliers, members of distribution channels, competitors, investors, employees, regulators, media and financial markets) (Raghubir et al. 2010). The ability of CSR to create corporate value is highly dependent on its ability to produce positive relationships with the stakeholders (Barnett, 2007). Scholarship as a CSR initiative should be viewed as a form of engagement to the community and a part of the company's investment rather than an expenditure. This type of CSR activity might affect the recipients' welfare or their quality of life and the business as well (e.g. positive image and community support). Previous studies have proven that CSR activities implemented by companies in Indonesia affected the recipients' quality of life (e.g. Balqiah et al. 2011). This study is a part of a larger study focusing on scholarship as a CSR initiative and the focus of this article is to describe the motives of the CSR activity from the side of the companies. This article will explore the community engagement in the form of education sponsorship in the CSR initiatives of two companies.

\section{Literature Review}

\section{Corporate Social Responsibility (CSR)}

Hopkins (2007) defined CSR as how firms treat their stakeholders ethically and responsibly. Ethical and responsible manners mean that the company treats its stakeholders in the civilized societies in an acceptable manner. These responsibilities include environmental responsibilities, economic responsibilities and creating a high standard of living while maintaining the company's performance (Hopkins, 2007). Kotler and Lee (2005) explained CSR as a firm's commitment to increase the community welfare through discretionary involvements and business practices.

There are three components regarding the principles of how companies should do their business responsibly (Vidaver-Cohen and Brønn, 2015). First, a company should implement sincere and transparent business transactions. Second, a company needs to have some concerns about 
stakeholders' welfare. Third, a company has to create values for the community. A company should focus not only on a specific stakeholder (i.e. customers) but also on the other stakeholders through various CSR initiatives (Maignan and Ferrell, 2004). Firms may choose several activities to implement their CSR such as promotions or funding, cause-related promotions (i.e. donating a portion of the company's sales) and doing charities (philanthropy) (Balqiah et al, 2017)

Lantos (2001) asserted that there are three types of CSR; ethical, altruistic and strategic. Ethical CSR stresses the demand for companies to conduct their business responsibly in order to prevent harm and injuries caused by their activities. Altruistic CSR means that the CSR is based on how the company sincerely cares and concerns for another's well-being. Strategic CSR is demonstrated when a company implements or initiates social activities or community services to achieve its business goals.

\section{CSR Motives}

According to Brønn and Vidaver-Cohen (2009), companies have three reasons for doing social activities; legitimacy profitability and sustainability motives. First, the legitimacy motive is the reason for carrying out social activities to meet stakeholders' expectations and protect the company's reputation. This motive is beneficial for a company to increase its ability to obtain resources, improve performance and build competitive advantage. Second, the profitability motive arises from the belief that the involvement in social activities will have a direct impact on finances through both revenue creation and the protection of corporate profitability. Lastly, the motive for sustainability is usually driven by the belief that corporate responsibility is a moral obligation and a company should contribute to preserving the world for future generations.

Other researchers conveyed that there are four motives behind the CSR activities carried out by the company from a consumer perspective, namely; valuedriven, stakeholder-driven, egoistic-driven and strategic driven (Ellen, Webb and Mohr, 2006). According to Ellen et al. (2006), the value motive is the company's belief to carry out CSR for the benefit of consumers and society and that they feel morally obligated to help. Stakeholder motives encourage CSR activities to meet the expectations and demands of stakeholders; consumers, employees, shareholders and the community. The egoistic motive is when a company implements its CSR activity to take some advantages such as to help its own business, to get publicity or to write-off the company's taxes. Strategic motives of the CSR are usually related to the company's growth (e.g. attracting new customers, retaining new customers or increasing profit).

The company, as an entity, is perceived as an institution that focuses on profit and will do anything in order to maximize profits. Therefore, when a company engages in CSR activities, there could be some suspicions from customers regarding the company's intentions. These suspicions cause customers to try to attribute the motives behind CSR activities carried out by the company. In general, there are two motives that encourage corporate CSR activities; namely; firm serving motives (i.e. for the good of the company) and public-serving motives (i.e. to help the community or to respond to the community's issues) (Ellen et al. 2006). Firm- serving motives are the company's motives in implementing CSR activities that aim at providing benefits to the company, for example, to increase profits, sales or build a positive image of a company or brand. Customers can attribute the company's CSR activities with these motives if the CSR activities carried out by the company are considered to have more benefits for the company (profit). According to Ellen et al. (2006), customers, in general, could accept the strategic motives of CSR (i.e. increasing sales or customers). However, customers would negatively evaluate the selfish motives or the exploitation of CSR activities solely for the company's interest.

Public-serving motives are company motives in carrying out CSR activities that are based on the company's desire to 
sincerely help the community or support the issues it promotes. Customers can attribute the company's CSR activities with these motives if the customer sees that the CSR activities carried out are of greater benefit to the community or the environment compared to the benefits the company receives. Customers' evaluation of CSR activities will be more positive if the activity is assessed as value-driven and the company sincerely wants to help the community/environment (Ellen et al. 2006).

\section{Methods}

This study was based on qualitative data derived from semi-structured interviews with representatives from two companies in different sectors. These companies were chosen because they had scholarship programs as their CSR initiatives and they represented two different company's characteristics. These companies were approached using the researchers' network. Company $\mathrm{A}$ is a state-owned company that operates in the field of natural resources (i.e. oil and gas) and company $B$ is the pioneer of halal cosmetics companies in Indonesia.

The interviews were conducted with one manager from each company and accompanied by their two staff members from the departments responsible for administering and organizing the scholarships for the university student's recipients. The interviews lasted between 60-90 minutes and were digitally recorded. Upon the completion of the interviews, the digital recordings were transcribed into Word documents for further analysis. To ensure anonymity, the coding results were identified by means other than participants' names, business name or other identifiable information. This study provided a comparative analysis between the two companies which had similar CSR initiatives. Patterns and regularities across these initiatives were identified. Quotes were also used to better illustrate key research findings. Although the two companies had several programs of CSR in education, this study only focused on the
CSR initiative related to the scholarship program for university students.

\section{Findings}

Company A is Indonesia's largest stateowned enterprise (SOE) that has been operating in the upstream and downstream sectors of the oil and gas industry for over than six decades. The upstream sector includes the exploration and production of oil, gas and geothermal energy, while its downstream activities cover the processing, marketing, trading and shipping. Company $A$ is a national energy company whose shares are $100 \%$ owned by the Government of the Republic of Indonesia through the State Ministry of State-Owned Enterprises (BUMN) as the Shareholders' Authority. The company's vision is to be a world-class national energy company, while its mission is to integrate their core business on strong commercial principles. The company has six core values; cleanliness, competition, confidence, customer focus, commerciality and capability. These values have been established and served as guidelines for all employees. Company A has had many CSR initiatives in education such as giving scholarships to students, revitalization of school facilities and organizing a national science Olympic competition for university students.

On the other hand, Company B is a private company that has been established since 1985 by a Muslim female pharmacist. At first, the company started as a home industry but now this company has been one of the largest companies in Indonesia which has two factories, 30 operational areas and around 4500 employees. The company has become a pioneer in introducing halal cosmetics in Indonesia and their products have been marketed not only in Indonesia but also in Malaysia and other countries in South East Asia. Company B commits to implementing the best management practices and develops itself continuously so it can always produce good quality products that are beneficial for employees, partners, communities and the environment. They have seven missions and one of the missions is to support national education and health. There are seven core 
values that are widely shared in the company: deity, exemplary, kinship, responsibility, customer focus and innovation. Education is one of the company's four CSR pillars and they have had several CSR programs in education, for example, trainings for teachers, scholarships for university students and family education. This study only focused on the company's initiative of giving scholarships to university students. The following paragraphs list several reasons why these companies provided a scholarship program for university students.

\section{The motives}

Social motives. The two companies in this study stated that the scholarship program they conducted was for charity. Company A started this program initially to help employees' children but gradually shifted and expanded to people outside the company. Company B also stated that they set aside $2.5 \%$ of the income for zakat (i.e. zakat is one of the five pillars in Islam by giving charity to the poor) and the company set a total of $7.5 \%$ for zakat activities and CSR activities of the company. The following comments illustrate this:

...At first, this program was initiated as a charity for helping employees' children to pursue their education, after that, we propose this scholarship initiative to help children from the community. (Manager, Company A)

..this is pure CSR, we are trying to help the economic problems of the students (recipients)...Islam teaches us to share $2.5 \%$ of our income for zakat (i.e. charity) and our company allocates $7.5 \%$ in total for doing our charity and all of our CSR programs. (Manager, Company B)

Company image. Both companies acknowledged that the scholarships as CSR activities carried out were also motivated to improve the company's image in the community. Company A also specifically mentioned that their businesses have had a large environmental impact, so the company felt the need to reduce their "guilt". As for Company B, they perceived that this program could increase company's exposure to the public through scholarship recipients. To illustrate, the participants commented as follows:

....the aim is to develop education in Indonesia and it also can be linked to the company's image. (Manager, Company A)

...the recipients were also happy having a plant tour and other exposures so that they could get to know our company better. (Staf 1, Company B)

Supporting education program in Indonesia. Company A perceived that with the scholarship program, the company could contribute to help in things the government cannot do. Company B stated that one of their company's missions is to support the health and education sectors so this program has been conducted to fulfill that mission. As the participants explained:

...we also want to contribute to support education in Indonesia, especially to help things that the government is still lacking. (Manager, Company A)

...one of our missions is to support education and our CEO always says that our existence must always bring benefits to many people. (Manager, Company B) 
Talent hunting. Although there are no guarantees for scholarship recipients to go straight to work at the company, Company $B$ perceived that these university students were potential to be recruited later in their firm and they also hoped that their scholarship program would be widely known, therefore it would increase the possibility to gain attention from university students and hopefully many of them would be interested in joining the company. This is evident in the manager's comment as follows:

\section{... we also expect that scholarship recipients can build their awareness of our company and in the future hopefully they are attracted to apply to our company as our employees. (Manager, Company B)}

Comply with regulations. This aspect arises from the information given by company A, as a company that operates in the oil and gas sectors in which they exploit natural resources, the CSR activities have also been perceived as mandatory. The following comment illustrates this:

\section{....So this is also the mandate of the law... (Manager, Company A)}

These companies recognize that the scholarship activity is beneficial for branding the company. The recipients of these scholarships were students who had the potential to become future talents in the company and according to Backhaus and Tikoo (2004), employer branding represents the company's efforts to promote internal and external parties and gives an idea of what makes the company a different and a desirable place for employees or prospective employee. Scholarship activities in these two companies were not just a corporate activity in giving money to recipients, company A also asks recipients to make activities especially those that can have a positive impact on the environment. This activity also gives a good impression not only to the recipient but also to the wider community, that the company is a good place as a career destination.

Both companies required scholarship recipients to carry out community projects such as tree planting activities, processing plastic waste or owning built villages and others. Both of these companies stated that they provided some funding for these activities, for example, company A provided funds of IDR 500,000/person/year and fellow scholarship recipients must work together to realize these social activities. Company B also provides additional development and exposure to recipients such as seminars and plant tours that will add insight into recipient students and become a venue for widely introducing the company.

There were similarities in the findings regarding their motives for giving a scholarship. However, due to the nature of the business of company A, the CSR program was also perceived as mandatory because according to Law of Republic Indonesia Number 40 of 2007 on Limited Liabilities Companies, article 74, "companies doing business in the field of and/or in relation to natural resources must put into practice Environmental and Social Responsibility".

Company B has always been perceived as the pioneer of halal cosmetics in Indonesia, and Islamic values are strongly held in the company. The examples of the Islamic values practiced in the company are Zakat (i.e. giving charity to the poor) and zakat is one of the five pillars in Islam and it is an obligation for Muslims. Zakat is a part of the Islamic Individual/Corporate Social Responsibilities. The amount of zakat to be paid is $2.5 \%$ of nisaab (i.e. the threshold at which Zakat becomes payable) and zakat can only be paid to specific beneficiaries and projects (Qur'an 9:60). Therefore, company $\mathrm{B}$ allocated $7.5 \%$ in total; $2.5 \%$ to fulfill the zakat and $5 \%$ to other companies' CSR activities. 


\section{Conclusions}

The findings of this exploratory study contribute to the small body of literature by exploring the motives of companies in doing their CSR activity, especially for the scholarship initiative. The findings showed that both companies had firm and publicserving motives in practicing their CSR (i.e. the scholarship program). Firm-serving motives are related to the strategic perspectives (e.g. image building, talent hunting, fulfilling the obligation or stakeholders' demands) and the publicserving motives are related to moral perspectives, which is based on the idea that business has an ethical duty to "give back" to society (Ellen et al. 2006). The findings also revealed that belief, value and religious thoughts might also be drivers for a company in practicing its CSR initiatives.

This study has limitations that tend to be generally found in exploratory studies such as the small sample size and the use of convenience sampling. Even though several companies were contacted from the university database to participate, not many companies responded for an interview. Therefore, the researchers used their own network to reach the company's participants. However, as noted, the main objective of the exploratory research is usually to lay the groundwork for future studies that focus on prediction and confirmation (Babbie, 2010). In such future, studies could focus on the motives of companies with similar characteristics, such as comparing the CSR motives among the state-owned companies or private companies in similar industries to explore the patterns.

There is a possibility that the company's representatives were affected by social desirability bias (Johnson and Fendrich, 2005), especially when they provided reasons why their company gave scholarships or conducted the CSR activity. This potential bias was counteracted by gathering perspectives from the scholarship recipients and the university as well (i.e. not covered in this paper).

The findings also revealed that belief, values and religious thoughts are also factors that trigger CSR activity. In such future work, researchers should examine the association between the thoughts and the intentions of organizations to implement their CSR activity.

\section{Acknowledgement}

Thank you to all informants and their organizations for their time and information during the research project. Also, for Vivie Nurjaningrum Putri for her help during the entire project.

\section{References}

- Babbie E. (2010), 'The practice of social research,' (12 ${ }^{\text {th }}$ ed.). Belmont, CA: Wadsworth Cengage Learning.

- Backhaus, K. and Tikoo, S. (2004), 'Conceptualizing and researching employer branding,' Career development international, 9(5), 501517.

- Balqiah, TE., Setyowardhani, H. and Khairani. (2011), 'The Influence of Corporate Social Responsibility Activity toward Customer Loyalty through Improvement of Quality of Life in Urban Area,'TheSouth East Asian Journal ofManagement, 5, 73-90.

- $\quad$ Balqiah, TE., Yuliati, E., Astuti, RD. and Sobari, N.(2017),'Corporate social responsibility: Linkage business performance and social performance,'The Southeast Asian Journal of Management, 11(2), 120-141.

- Barnett, M.L. (2007),'Stakeholder influence capacity and the variability of financial returns to corporate social responsibility,'Academy of Management Review, 32(3),794-816.

- Benn, S. and Bolton, D.(2011),'Key concepts in corporate social responsibility', Sage.

- Brønn, PS. and Vidaver-Cohen, D. (2009),'Corporate Motives for Social Initiative: Legitimacy, Sustainability, or the Bottom Line?,'Journal of Business Ethics, 87, 91-109.

- Buchholtz, AK. and Carroll, AB.(2008), 'Business and Society', SouthWesternCengage Learning.

- $\quad$ Ellen., P. S., Webb, D. J. and Mohr, L. A. (2006), 'Building Corporate 
Association: Consumer Attributions for Corporate Socially Responsible Program,'Journal of the Academy of Marketing Science, 34(2),147-157.

- Hopkins, M. (2007), 'Corporate Social Responsibility \& International Development: Is Business the Solution?',Earthscan, London.

- Johnson, T. and Fendrich, M. (2005). 'Modeling sources of self-report bias in a survey of drug use epidemiology,' Annals of epidemiology, 15(5), 381-389.

- Kiessling, T., Isaksson, L. and Yasar, B. (2015), 'Market Orientation dan CSR:Performance Implications,'Journal of Business Ethics, 102(1),47-55.

- $\quad$ Kotler, P. and Lee, N. (2005),'Corporate Social Responsibility: Doing the Most Good for Your Company and Your Cause,' John Wiley andSons.

- Lantos, G.P. (2001),'The boundaries of strategic corporate social responsibility,'Journal of consumer marketing, 18(7), 595-632.

- Law of Republic Indonesia Number 40 of 2007 on Limited Liabilities Companies.

Maignan, I. and Ferrell, OC. (2004),'Corporate social responsibility and marketing: an integrative framework.,'Journal of the Academy of Marketing Science, 32(1),3-19.

- Pearce, C.L. and Manz, C.C., 2011. Leadership centrality and corporate social irresponsibility (CSIR): The potential ameliorating effects of self and shared leadership on CSIR. Journal of Business Ethics, 102(4), p.563.

- Peloza,J. and Shang,J.(2011),'Howcancorporatesocial responsibilityactivitiescreatevalue for stakeholders?A systematicreview,'Journal of the Academy of Marketing Science, 39(1), 117-135.

- Qur'an 9:60. (2013), translated by Abdullah Yusuf Ali. Ware, Hertfordshire: Wordsworth Editions Limited.

- $\quad$ Raghubir, P., Roberts, J., Lemon, K. and Winer, RS. (2010),'Why, When, and How Should the Effect of Marketing be Measured? A Stakeholder Perspective for Corporate Social Responsibility,'Journal of Public Policy and Marketing, 29, 66-77.

- Torugsa, N., O'Donohue., W. and Hecker, R. (2013),'Proactive CSR: An Empirical Analysis of the Role of its Economics, Social and Environmental Dimensions on the Association between Capabilities and Performance,'Journal of Business Ethics, 115,383-402.

- Vidaver-Cohen, D. and Brønn, P.S. (2015), 'Reputation, responsibility, and stakeholder support in Scandinavian firms: A comparative analysis,' Journal of Business Ethics, 127(1), 49-64. 